\title{
Lysinibacillus massiliensis Isolated from the Synovial Fluid: A Case Report
}

\section{Sinoviyal Sıvıdan İzole Edilen Lysinibacillus massiliensis. Olgu Sunumu}

\author{
Canan ERYILDIZ'(IID), Kıymet TABAKÇIOG̃LU(IID), Sezgin KEHAYA³(IID), Nermin ȘAKRU'(IiD), Șaban GÜRCAN'(IiD) \\ ${ }^{1}$ Department of Medical Microbiology, School of Medicine, Trakya University, Edirne, Turkey \\ ${ }^{2}$ Department of Medical Biology, School of Medicine, Trakya University, Edirne, Turkey \\ ${ }^{3}$ Department of Neurology, School of Medicine, Trakya University, Edirne, Turkey
}

Cite this article as: Eryıldız C, Tabakçığlu K, Kehaya S, Şakru N, Gürcan Ş. Lysinibacillus massiliensis isolated from the synovial fluid: a case report FLORA 2020;25(4):595-8.

\begin{abstract}
Lysinibacillus massiliensis is an aerobic, endospore-forming, gram-negative staining bacterium with peritrichous flagella belonging to the Bacillaceae family. A few cases of L. massiliensis isolated from the cerebrospinal fluid and tissue have been reported. In this study, we aimed to describe a case of $L$. massiliensis isolated from the synovial fluid. The synovial fluid from a 74-year-old female patient was inoculated into blood culture bottle. Gram-negative rods were observed in a gram-stained smear from a positive blood culture bottle. The bacterium was identified as Lysinibacillus sphaericus/Lysinibacillus fusiformis, with a probability of $89 \%$ using an automated bacterial identification system (VITEK2; Biomerieux, France). Subsequently, 16S rRNA gene sequencing was performed, and the sequence was analyzed using the Basic Local Alignment Search Tool. The sequence had 99.9\% (1426/1427) identity with the strain L. massiliensis (GenBank ID: NR_043092.1). To our knowledge, this is the first reported case of L. massiliensis isolated from the synovial fluid. When an endospore-forming gram-negative staining bacterium can not be identified by phenotypic characterization, L. massiliensis should be considered, and different microbiological methods should be used for identification.
\end{abstract}

Key Words: Lysinibacillus massiliensis; Synovial fluid; 16S rRNA gene sequencing 
ÖZ

\title{
Sinoviyal Sıvıdan İzole Edilen Lysinibacillus massiliensis. Olgu Sunumu
}

\author{
Canan ERYILDIZ1', Kıymet TABAKÇIOG̃LU², Sezgin KEHAYA ${ }^{3}$, Nermin ȘAKRU', Șaban GÜRCAN'
}

\footnotetext{
${ }^{1}$ Trakya Üniversitesi Tıp Fakültesi, Tıbbi Mikrobiyoloji Anabilim Dalı, Edirne, Türkiye

2 Trakya Üniversitesi Tıp Fakültesi, Tıbbi Biyoloji Anabilim Dalı, Edirne, Türkiye

3 Trakya Üniversitesi Tıp Fakültesi, Nöroloji Anabilim Dalı, Edirne, Türkiye
}

\begin{abstract}
Lysinibacillus massiliensis aerobik, endospor oluşturan, gram-negatif boyanan, peritrik flajellaya sahip, Bacillaceae ailesine ait bir bakteridir. Bakterinin serebrospinal sıvı ve dokudan izole edildiği az sayıda olgu rapor edilmiştir. Bu çalışmada sinoviyal sıvıdan L. massiliensis'in izole edildiği bir olgu sunulmaktadır. 74 yaşında kadın hastanın kan kültür şişesine ekilen sinoviyal sıvısında gram-negatif boyanan bakteriler görülmüştür. Bakteri VITEK2 (Biomerieux, Fransa) bakteri tanımlama sistemi ile \%89 olasılıkla Lysinibacillus sphaericus/ Lysinibacillus fusiformis olarak isimlendirilmiştir. Bakterinin 16S rRNA gen dizi analizi yapılmış ve elde edilen dizi "Basic Local Alignment Search Tool" ile analiz edilmiştir. Dizinin \%99.9 (1426/1427) oranında Lysinibacillus massiliensis (GenBank ID: NR_043092.1) suşu ile benzerlik gösterdiği saptanmıştır. Bildiğimiz kadarıyla bu olgu literatürde, sinoviyal sıvıdan L. massiliensis'in izole edildiği ilk olgudur. Endospor oluşturan ve gram-negatif boyanan bir bakteri fenotipik yöntemlerle isimlendirilemediğinde L. massiliensis akla getirilmeli ve tanımlamada farklı mikrobiyolojik yöntemler kullanılmalıdır.
\end{abstract}

Anahtar Kelimeler: Lysinibacillus massiliensis; Sinoviyal sIvi; 16 S rRNA gen dizileme

\section{INTRODUCTION}

Lysinibacillus species are environmental bacteria that belong to the Bacillaceae family ${ }^{[1,2]}$. Although most members of the Bacillaceae family stain gram-positive, some species of the family stain gram variable or gram-negative ${ }^{[3]}$. Glazunova et al. have previously isolated a bacterium from a sample of the cerebrospinal fluid and identified it as aerobic, with peritrichous flagella and endospore-forming gram-negative staining rod. The bacterium was included in the Bacillus sphaericus-like group and named Bacillus massiliensis ( $B$. massiliensis) based on $16 \mathrm{~S}$ rRNA gene sequence analysis and phenotypic characteristics ${ }^{[4]}$. B. massiliensis was later included in the Lysinibacillus genus and renamed Lysinibacillus massiliensis ( $L$. massiliensis) on the basis of DNA-DNA hybridizations and phenotypic tests ${ }^{[5]}$. A few human cases of $L$. massiliensis have been reported, where the bacterium was isolated from the cerebrospinal fluid and tissue $e^{[4,6]}$. To our knowledge, this is the first reported case of $L$. massiliensis isolated from the synovial fluid.

\section{CASE REPORT}

A 74-year-old female patient with cerebrovascular disease was admitted to the neurology clinic. The patient had Wallenberg syndrome, a history of gout, chronic renal failure, and hypertension. She had no immunosuppressive disease or drug use. On the third day of hospitalization, the patient complained of swollen knees, pain, and limitations of joint range of motion. Physical examination revealed pain, a slightly elevated local temperature, and suprapatellar swelling on the left knee. Ultrasonography showed suprapatellar bursitis. Routine laboratory analyzes revealed white blood cell count of 14,400 cells $/ \mathrm{mm}^{3}$ (reference range: 3,980-10,040 cells $/ \mathrm{mm}^{3}$ ) and C-reactive protein of $8.28 \mathrm{mg} / \mathrm{dL}$ (reference range: 0-0.8 mg/dL). The synovial fluid was sent to the microbiology laboratory for culture. Subsequently, ampicillin-sulbactam therapy $(1.5 \mathrm{~g} / 6 \mathrm{~h}, \mathrm{IV})$ was started empirically. In the microbiological analyzes, 6,400 cells $/ \mathrm{mm}^{3}$ and $95 \%$ polymorphonuclear leukocytes were observed in the synovial fluid. The synovial fluid was inoculated into a BacT/ ALERT bottle and incubated in a BacT/ALERT 3D microbial detection system (Biomerieux, France). A positive signal was detected on the second day of culture. Gram-negative rods were observed in a gram-stained smear from a positive blood culture bottle. Antimicrobial therapy was changed to piperacillin-tazobactam $(2.25 \mathrm{~g} / 6 \mathrm{~h}$, IV). On 
the $10^{\text {th }}$ day of antibiotic use, the patient had stable vital findings and was discharged, with the advice to return for a follow-up visit. The bacterium was identified as Lysinibacillus sphaericus/ Lysinibacillus fusiformis, with a probability of $89 \%$ using an automated bacterial identification system (VITEK2; Biomerieux, France). Minimum inhibitory concentration values for penicillin, levofloxacin, vancomycin and clindamycin were detected as $0.064 \mu \mathrm{g} / \mathrm{mL}, 0.5 \mu \mathrm{g} / \mathrm{mL}, 0.094 \mu \mathrm{g} / \mathrm{mL}$ and $0.5 \mu \mathrm{g} / \mathrm{mL}$ by gradient strip test (Biomerieux, France). A bacterial DNA sample was isolated from the microbial culture using a commercial kit (PureLink Genomic DNA Mini Kit; ThermoFisher Scientific, USA) according to the manufacturer's protocol. Polymerase chain reaction (PCR) of the 16S rRNA gene was performed using universal primers $\mathrm{fD} 1$ and $\mathrm{rP}_{2}{ }^{[7]}$. The $\mathrm{PCR}$ products were purified using a commercial kit (PureLink PCR Purification Kit; ThermoFisher Scientific, USA), and sequencing PCR was carried out using an Applied Biosystems BigDye Terminator v3.1 Cycle Sequencing Kit (ThermoFisher Scientific, USA). Capillary electrophoresis was conducted on an Applied Biosystems 3500 Series Genetic Analyzer (ThermoFisher Scientific, USA). Raw data were aligned by ProSeq v2.9 and analyzed using BioEdit software. As a result of the alignments, a 1.427 bp-long sequence was obtained. The sequence was analyzed using the Basic Local Alignment Search Tool. The sequence had 99.9\% (1426/1427) identity with the strain L. massiliensis (GenBank ID: NR_043092.1). The nucleotide at position 69 of the sequence was guanine, and the corresponding nucleotide of the reference sequence was guanine or thymine. The other nucleotides of the sequence were a match for those of $L$. massiliensis. The obtained sequence was submitted to the DNA Data Bank of Japan database (Accession no. LC500856).

\section{DISCUSSION}

L. massiliensis has rarely been isolated in clinical specimens. We found two case reports of L. massiliensis in the academic literature. In one case, L. massiliensis was isolated from human cerebrospinal fluid and classified as B. massiliensis $^{[4]}$. In another case, it was detected in tissue culture from a patient who had received an autologous, adipose-derived stem cell injection to the perianal region. The bacterium was identified as Lysinibacillus massiliensis by phenotypic characterization and $16 \mathrm{~S}$ rDNA sequencing ${ }^{[6]}$.

In the present case, clinical findings, leukocytosis, and increased C-reactive protein were indicative of a pyogenic infection. However, the low number of cells in the synovial fluid was not compatible with bacterial infection. Blood culture was not taken from the patient. Nevertheless, the bacterium was isolated from a region that should be sterile, and the patient responded to antimicrobial treatment. Considering the clinical status of the patient, chronic renal failure was thought to be the most likely risk factor. However, Lysinibacillus species were found in environmental habitats such as soil and surface water. Moreover, the bacteria were isolated from air sample collected from a medical practice room ${ }^{[2,8]}$. Consequently, the possibility that the isolate in the present case was a contaminant can not be excluded.

In microbiology laboratories, it is necessary to use different methods for the identification of bacteria that are rarely isolated and can not be identified by phenotypic methods. For these purposes, 16S rRNA gene sequence analysis is very useful in such cases ${ }^{[9-11]}$. When an endospore-forming gram-negative staining bacterium can not be identified by phenotypic methods, $L$. massiliensis should be considered, and different microbiological methods should be used in such cases.

\section{CONFLICT of INTEREST}

The authors have disclosed that they do not have any potential conflicts of interest.

\section{AUTHORSHIP CONTRIBUTIONS}

Concept/Design: CE, NŞ

Analysis/Interpretation: CE, KT, SG

Data Acquisition: CE, SK

Writting: CE, KT, SG, NȘ

Final Approval: All of authors 


\section{REFERENCES}

1. Ahmed I, Yokota A, Yamazoe A, Fujiwara T. Proposal of Lysinibacillus boronitolerans gen. nov. sp. nov., and transfer of Bacillus fusiformis to Lysinibacillus fusiformis comb. nov. and Bacillus sphaericus to Lysinibacillus sphaericus comb. nov. Int J Syst Evol Microbiol 2007;5 7:111 7-25.

2. Zhao F, Feng Y, Chen R, Zhang J, Lin X. Lysinibacillus alkaliphilus sp. nov., an extremely alkaliphilic bacterium, and emended description of genus Lysinibacillus. Int I Syst Evol Microbiol 2015;65:2426-31.

3. Logan NA, De Vos P. Bacillaceae. In: De Vos P, Garrity GM, Jones $D$, Krieg NR, Ludwig W, Rainey FA, Schleifer KH, Whitman WB (eds). Bergey's Manual of Systematics Bacteriology. $2^{\text {nd }}$ ed. New York: Springer, 2009:20-228.

4. Glazunova OO, Raoult D, Roux V. Bacillus massiliensis $s p$. nov., isolated from cerebrospinal fluid. Int I Syst Evol Microbiol 2006;56(7):1485-8.

5. Jung MY, Kim JS, Paek WK, Styrak I, Park IS, Sin Y, et al. Description of Lysinibacillus sinduriensis sp. nov., and transfer of Bacillus massiliensis and Bacillus odysseyi to the genus Lysinibacillus as Lysinibacillus massiliensis comb. nov. and Lysinibacillus odysseyi comb. nov. with emended description of the genus Lysinibacillus. Int I Syst Evol Microbiol 2012;62:2347-55.

6. Jin JJ, Keith PJ, Cummins NW, Kane SV, Pritt BS, Sanchez JL. Lysinibacillus massiliensis panniculitis masquerading as erythema nodosum: A case report. Open Forum Infect Dis 2017;4(2):ofx072.
7. Weisburg WG, Barns SM, Pelletier DA, Lane DJ. 165 ribosomal DNA amplification for phylogenetic study. I Bacteriol 1991;173(2):697-703.

8. Seiler H, Scherer $S$, Wenning M. Lysinibacillus meyeri sp. nov., isolated from a medical practice. Int / Syst Evol Microbiol 2013;63(4):1512-8.

9. Patel JB. 16S rRNA gene sequencing for bacterial pathogen identification in the clinical laboratory. Mol Diagn 2001;6(4):313-21.

10. Gürcan Ş, Ünlü S, Kuloğlu F, Karadenizli A, Kuşkucu MA. Microbiological approach to a possible infective endocarditis case caused by Aggregatibacter actinomycetemcomitans. Mikrobiyol Bul 2016;50(2):315-21.

11. Eryıldız C, Gürcan Ş, Bukavaz Ş, Hatipoğlu O. A rarely isolated bacterium in microbiology laboratories: Streptococcus uberis. Mikrobiyol Bul 2017;51(2):171-6.

\section{Address for Correspondence/Yazıșma Adresi}

\section{Dr. Öğr. Üyesi Canan ERYILDIZ}

Trakya Üniversitesi Tıp Fakültesi,

Tıbbi Mikrobiyoloji Anabilim Dalı, Edirne-Türkiye

E-mail: cananeryildiz@gmail.com 